\title{
Attenuation of intestinal efflux pump thru polymers and preservatives
}

\author{
Ramin MOHAMMADZADEH ${ }^{1,2}$ (D), Behzad BARADARAN ${ }^{3}$ (D), Bahman YOUSEFI ${ }^{3}$ (D), \\ Hadi VALIZADEH 2 (D), Parvin ZAKERI-MILANI 2,4 * (D)
}

1 Student Research Committee and Faculty of Pharmacy, Tabriz University of Medical Sciences, Tabriz, Iran.

2 Drug Applied Research Center and Faculty of Pharmacy, Tabriz University of Medical Sciences, Tabriz, Iran.

3 Immunology Research Center and School of Medicine, Tabriz University of Medical Sciences, Tabriz, Iran.

4 Liver and Gastrointestinal Diseases Research Center and Faculty of Pharmacy, Tabriz University of Medical Sciences, Tabriz, Iran.

* Corresponding Author. E-mail: pzakeri@tbzmed.ac.ir (P.ZM.); Tel. +98-413-334 1315.

Received: 14 January 2019/ Revised: 11 March 2019/ Accepted: 14 March 2019

\begin{abstract}
P-glycoprotein (P-gp), the efflux membrane protein found in the upper exterior of epithelial cells in human intestine, is capable of exhibiting variations in the intestinal transport. This study was set with the purpose of testing the capability often pharmaceutical excipients namely Carbopol, Xanthan, Tragacanth, Sodium Benzoate, Hydroxypropyl methylcellulose, Methylparaben, Methylcellulose, Cetyltrimethylammonium bromide and Vitamin E in regulating $\mathrm{P}$-gp protein expression and the multidrug resistance (MDR1) gene, by means of a monolayer of human colon cancer cell line (Caco-2). Using MTT test, the least sub-toxic concentrations of mentioned excipients were assessed in Caco-2 cells. Subsequently the impact of the excipients on P-gp activity was evaluated by quantifying the amount of Rhodamine-123 uptake into cells. Besides, P-glycoprotein expression was scrutinized via Western-blotting. Among the tested excipients, Tragacanth and Xanthan showed a similar western blotting and Rhodamine-123 assay results as the control group. Carbopol 934, Vitamin E, and Methylcellulose showed 27.2\%, 43\% and 50.9\% increase in Rhodamine accumulation, respectively. According to the obtained results it is concluded that using appropriate concentrations of the Carbopol 934, Vitamin E and Methylcellulose can attenuate the P-gp activity and expression where such reduction ought to be taken into consideration due to its role in the changes of permeability and absorption of the pharmaceutical compounds.
\end{abstract}

KEYWORDS: Excipients; P-glycoprotein; ABCB1; intestinal efflux pump; Rhodamine-123.

\section{INTRODUCTION}

Oral route for drug administration, covering $85 \%$ of drugs sold around the world, has many benefits and is known as a convincing way for drug delivery, both for systemic and local drug delivery. Oral pharmaceuticals are the most desirable choice for pharmacotherapy of diseases due to their simplicity of design, wide variegation of formulations and notably, high patient compliance especially for chronic drug administration [1-3]. Many factors were reported to have impact on the gastrointestinal absorption of drugs which possess low rates of solubility, extensive first-pass effect, efflux transport, low permeability [4, 5], etc.

ATP-binding cassette $(\mathrm{ABC})$ proteins act as membranous transporters consuming the energy produced by the hydrolysis in order to transport different materials through cellular membranes. Of this superfamily, P-glycoprotein, also known as ABCB1 (ATP-binding cassette subfamily B member 1), as a drug efflux pump through human intestine which is encoded by MDR1 gene, displays an important function in the intestinal efflux process while it is also noted to be responsible for the efflux of many anticancer drugs [6, 7]. This effect of P-gp is mentioned as a defense mechanism in contradiction to toxic agents and it is capable of making a reduction in the rate of bioavailability of a vast number of pharmaceuticals [8].

On the other hand, excipients, ingredients other than the pharmaceutically active drugs that occupy the majority volume of oral and parenteral medications, were formerly known as inert particles [9]. However, these substances are capable of potential changes and effects on drug stability, metabolism and efflux [10-12].

How to cite this article: Mohammadzadeh R, Baradaran B, Yousefi B, Valizadeh $\mathrm{H}$, Zakeri-Milani P. Attenuation of intestinal efflux pump thru polymers and preservatives. J Res Pharm. 2019; 23(4): 632-641. 
As stated by recent studies, a number of different agents and excipients would interrupt the efflux caused by P-gp. Several papers have described information on the noteworthy properties of different excipients which affect on drug absorption and permeability thru intestinal efflux pump. Such as, a previous study reported that tween 80 can shrink the fraction of serosal-mucosal transport to mucosal-serosal transport for Rho-123 through rat jejunal membrane in vitro and caco-2 cell monolayer evocative of p-gp inhibition [13]. Into the bargain, the in vitro amount of absorption for digoxin through a rat gut sac (a p-gp substrate) revealed an intense growth in amounts after treating with $0.5 \%(\mathrm{w} / \mathrm{v})$ tween 80 and tween 20 [14]. Correspondingly, digoxin given with tween 80 showed an increase in AUC and Cmax in rats. Another study has claimed that cremophor EL $(0.1 \%, \mathrm{w} / \mathrm{v})$ only partially inhibits P-gp activity in Caco-2 cells [15]. Lipid excipients Peceol and Gelucire 44/14 decrease P-glycoprotein mediated efflux of Rhodamine 123 partially due to modifying Pglycoprotein protein expression within Caco-2 cells [16].

Granting these findings, we selected ten excipients whose impact on the P-gp has not been reported yet. They were namely, Xanthan, Tragacanth, Carbopol 934, Sodium Benzoate (NaB), Hydroxypropyl methylcellulose (HPMC), Methylcellulose (MC), Methylparaben (MP),Cetyltrimethylammonium bromide $(\mathrm{CTAB})$ and Vitamin $\mathrm{E}$.

Xanthan gum (XG), a water-soluble, high-molecular-weight, heteropolysaccharide of calcium, sodium, and potassium acquired from the aerobic fermentation of a carbohydrate with Xanthomonas campestris. It is a low-viscosity solution that forms viscoelastic gels. The viscous gels reduce the drainage and improve the contact time better than conventional eye drops. XG has been used in combination with other polymers to increase viscosity of the solutions. Cross linking structure of xanthan controls the release of drugs and it exhibits a near zero order drug release [17]. Tragacanth gum which is a biodegradable and biocompatible polymer that is used as an emulsifying agent, rheology enhancer, etc. [18]. Carbopol Polymer is a self-wetting, rheology modifier designed to be used as a thickener, suspending agent and stabilizer in cosmetic manufacturing. Its unique structure allows it to rapidly expand when added to liquids and provides moderateto-high viscosity in skin care products. Carbopol polymer performs effectively across a broad $\mathrm{pH}$ range, making it a versatile ingredient for many applications [19]. Sodium benzoate (NaB), a metabolite of cinnamon, is a commonly used food preservative and an FDA-approved therapy for reducing plasma ammonia and glutamine in urea cycle disorders [20]. Sodium benzoate ( $\mathrm{NaB})$, in low concentrations, is used in aqueous solutions [21]. Hydroxypropyl methylcellulose (HPMC), a semi-synthetic cellulose derivative, has been most frequently studied in the formulation of monolithic matrix tablets for controlled release, due to its hydrophilic gel-forming property, non-toxicity and cost-effectiveness. In addition, this polymer can be formulated with several drugs, being able to accommodate high levels of these molecules [22, 23]. Methylcellulose (MC) is a non-fouling hydrogel structure in which the thermoresponsive assets is engaging for neural tissue engineering uses, for the most part, for conditions where the implanted material requires to fit into the erratically shaped lesions/defects [24, 25]. Methylparaben (MP) has been used for the protection of active substances in the dose formulation [26-28]. Cetyltrimethylammonium bromide (CTAB) is an active antiseptic agent against microorganisms. It is utilized for providing a buffer solution intended for the extraction of DNA. Also, it has been extensively used in production of gold nanoparticles [29]. Finally, vitamin E which is a lipophilic antioxidant and has been known to have a key role in the prevention of cancer, is shown to be effective in the prevention of chronic [30]

Subsequently, this study was set in order to evaluate the potential and probable effects of the named materials on the expression and activity of P-gp protein. This could be pursued by an enhancement in drug bioavailability due to the design and co-administration of different drugs with these excipients. This would be possible after the characterization of the altering and various effects of different excipients on the efflux pump.

\section{RESULTS}

\subsection{Safe concentrations and cell viability assay}

The most bearable dosage for every excipient over Caco-2 cells was revealed using MTT assay test. So, two maximum safe concentrations were carefully chosen for treating cells in the tests of the uptake of the Rhodamine-123 and western blotting assessment. The results for MTT assay for Vitamin E, Carbopol, Xanthan and Tragacanth are displayed in Figure 1 and the results for NaB, HPMC, MP, MC and CTAB are presented in Figure 2. Considering these data, $0.5 \%(\mathrm{w} / \mathrm{v})$ and $1 \%(\mathrm{w} / \mathrm{v})$ were the selected concentrations for further 
studies while concentrations above $0.1 \%(\mathrm{w} / \mathrm{v})$ and $0.25 \%(\mathrm{w} / \mathrm{v})$ of Carbopol and Xanthan were toxic for Caco2 cells. Toxic concentrations were $0.25 \%(\mathrm{w} / \mathrm{v})$ and $0.5 \%(\mathrm{w} / \mathrm{v})$ for Tragacanth, $0.02 \%(\mathrm{w} / \mathrm{v})$ and $0.05 \%(\mathrm{w} / \mathrm{v})$ for MP, $0.05 \%(\mathrm{w} / \mathrm{v})$ and $0.1 \%(\mathrm{w} / \mathrm{v})$ for $\mathrm{NaB}, 0.25 \%(\mathrm{w} / \mathrm{v})$ and $0.5 \%(\mathrm{w} / \mathrm{v})$ for CTAB, $0.1 \%(\mathrm{w} / \mathrm{v})$ and $0.25 \%$ $(\mathrm{w} / \mathrm{v})$ for HPMC K15M, $0.1 \%(\mathrm{w} / \mathrm{v})$ and $0.25 \%(\mathrm{w} / \mathrm{v})$ for MC. Consequently, minor concentrations were employed for uptake test and western blotting. The samples for the excipients were prepared by preparing a solution of each in water with ethanol. The maximum fraction of the ethanol was $10 \%$ in order not to damage the viable cells.

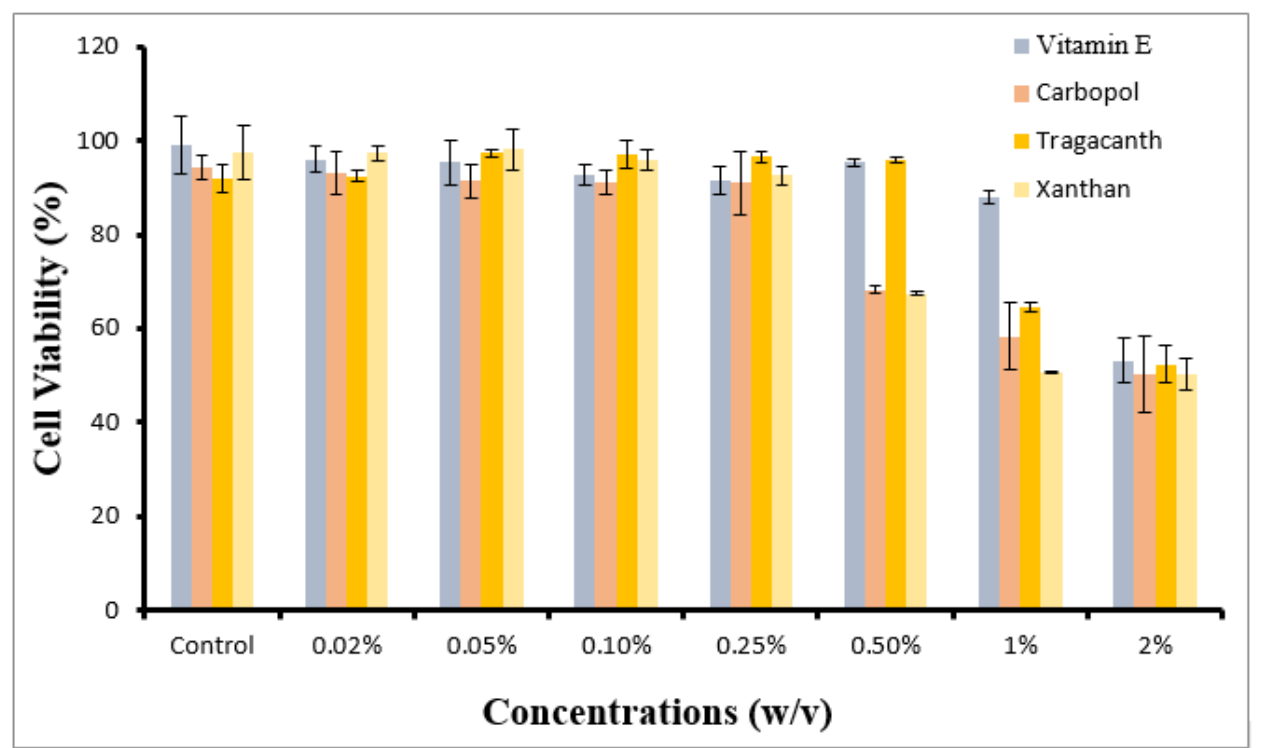

Figure 1. Effects of Vitamin E, Carbopol, Xanthan and Tragacanth among the viability of the Caco-2 cells after exposure for 24 hours to the excipients. Data has been established using cell viability in a hundred in comparison to the control cells subsequently \pm standard deviation of no less than 3 measurements.

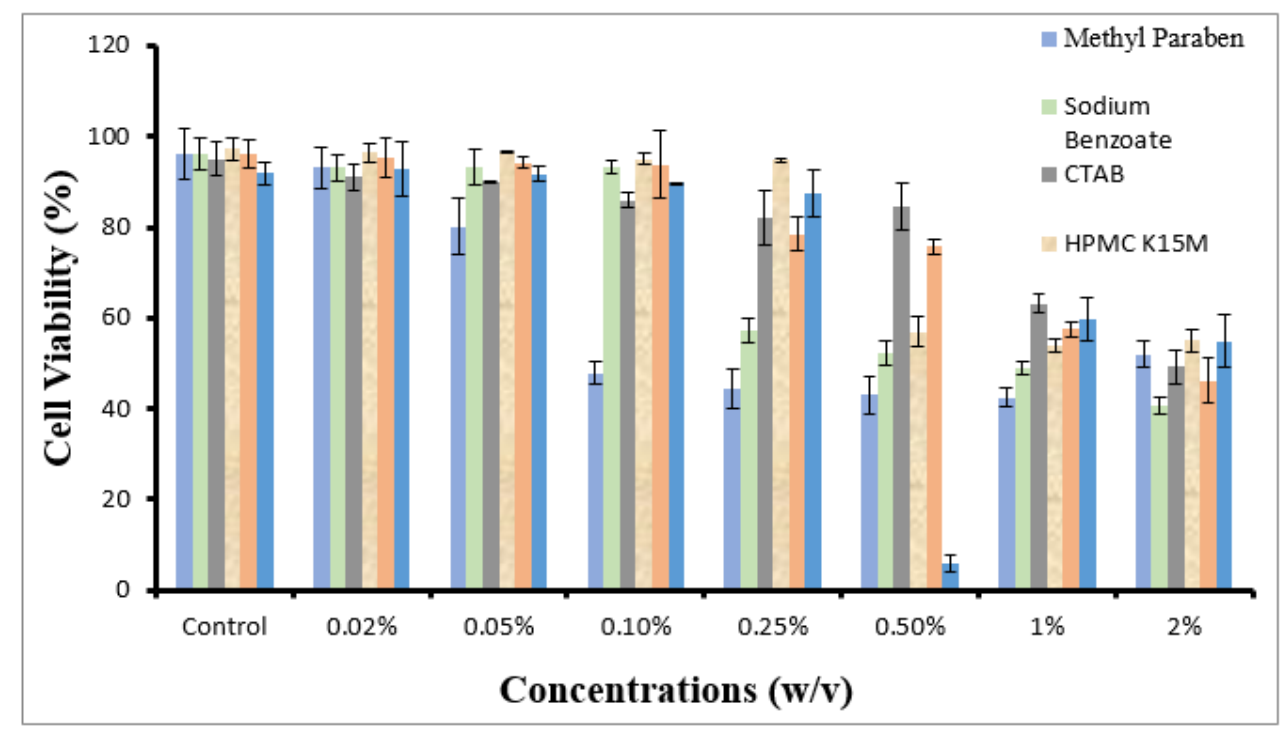

Figure 2. Effects of $\mathrm{MP}, \mathrm{NaB}, \mathrm{CTAB}, \mathrm{HPMC}$ and $\mathrm{MC}$ among the viability of the Caco-2 cells after exposure for 24 hours to the excipients. Data has been established using cell viability in a hundred in comparison to the control cells subsequently \pm standard deviation of no less than 3 measurements. 


\subsection{Rho-123 accumulation assays}

Methylcellulose 0.25\% (w/v) Carbopol 0.25\% (w/v) and Vitamin E 1\% (w/v) enhanced Rhodamine-123 accumulation inside the Caco- 2 cell lines, significantly which are presented via Figure 3.

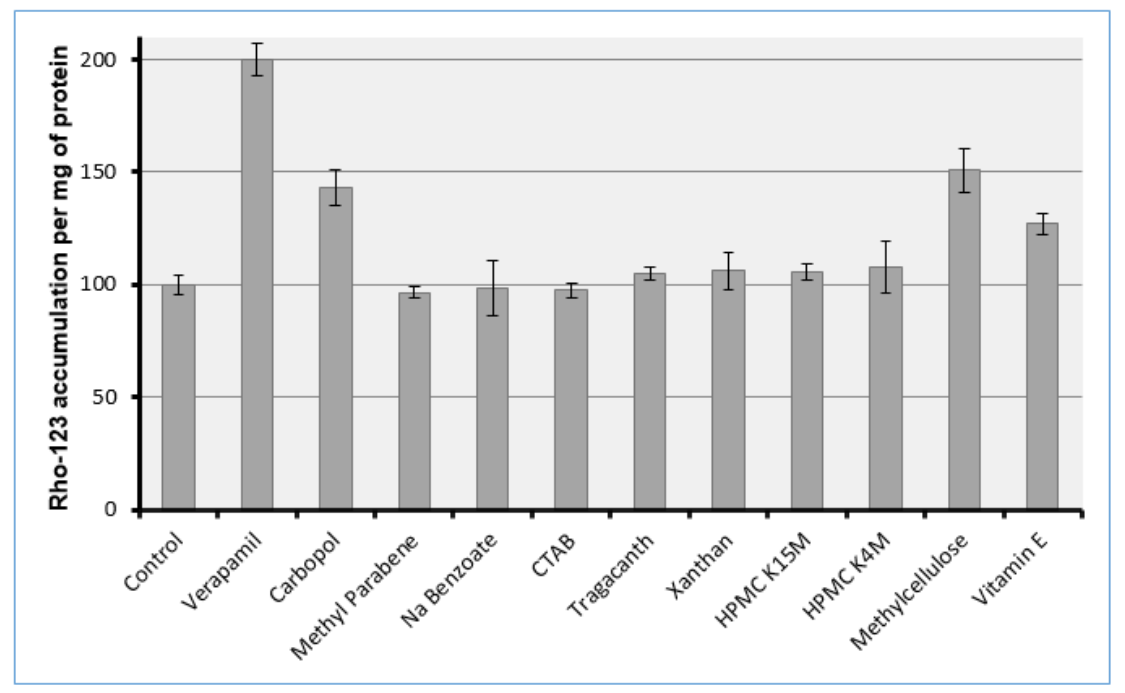

Figure 3. Effect of Vitamin E, Carbopol, Xanthan, Tragacanth, NaB, HPMC, MP, MC and CTAB on Rhodamine-123 accumulation inside the Caco-2 cell lines. The amount of Rho-123 accumulation $(\mathrm{mg} \times 106 / \mathrm{mL})$ was collated and put on show in contrast to overall protein $(\mathrm{mg} / \mathrm{mL})$ of each well. Data has been compared to the control group by means of one-way ANOVA through Student-Newman-Keuls post hoc test $\left({ }^{*} \mathrm{P}<0.001\right) .0 .3 \mathrm{mM}$ verapamil which is $\mathrm{P}$-gp inhibitor, used as the internal standard (positive control).

\subsection{Western blot analysis}

Carbopol 934, Vitamin E and Methylcellulose attenuated the P-gp expression through Caco-2 cells and subsequently decrease the activity of efflux pump. Results for the rest used excipients showed a smaller amount of change in comparison to control group. Data are represented via Figures 4 and 5.

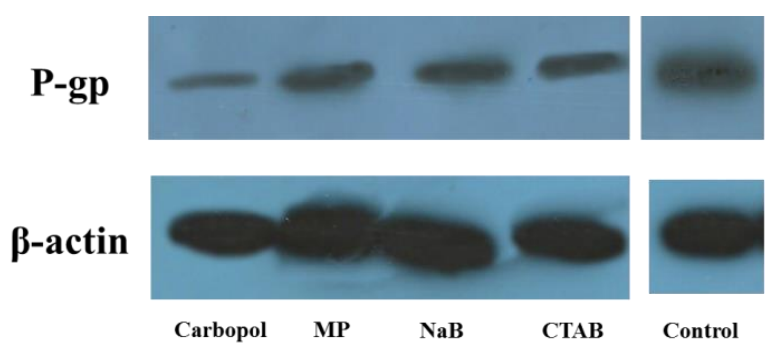

Figure 4. P-gp expression within 24 hours' treatment with Carbopol 934, Methylparaben, Sodium benzoate and CTAB. ( $\beta$-actin was considered as the internal standard).

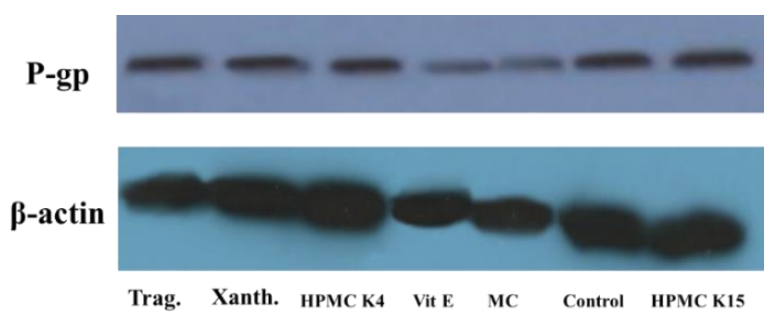

Figure 5. P-gp expression within 24 hours' treatment with Tragacanth, Xanthan, HPMCK4M, Vitamin E, Methylcellulose and HPMCK15M. ( $\beta$-actin was considered as the internal standard). 


\section{DISCUSSION}

Adequate knowledge of the elements adjusting the expression and role of intestinal P-gp is vital both from the clinical and toxicological outlooks. The results of this study, which were obtainable at this point, revealed the possible influence of the used excipients and preservatives on the intestinal efflux pump by which reduced the expression of P-glycoprotein and its activity on Caco-2 monolayer cell lines. Excipients were assessed through MTT assay to calculate and determine their cytotoxic concentrations and the achieved results were used in the accumulation studies of Rhodamine-123. Moreover, Rho-123 concentration records were established by means of western blotting assessment.

According to the obtained results Carbopol, Methylcellulose and Vitamin E increased the amount of Rho-123 accumulated inside the cells and reduced P-gp appearance concurrently. Our work intended to achieve a sensible medicinal preparation development scheme for oral pharmaceuticals as the oral route is the most common and appropriate path to target drugs to their destinations in the body followed by highest compliance [31]. On the other hand, MDR proteins belonging to ABC transporters are a part of membrane transport proteins that detoxify cells from external substrates. These proteins were identified to limit the absorption through biological membranes such as intestinal, brain and cancer cells. [32-34]

P-glycoprotein as a fundamental member in the performance of absorption, distribution and elimination in an extensive range of medications through the human intestine, transport cytotoxic agents away of the internal part of the cells in the direction of through to the lumen which subsequently decreases the concentration of the pharmaceutical agents and the toxicity thereof. Consequently, P-gp attenuates the bioavailability of the drugs which are consumed via oral route [35].

In the brain, efflux pump thwarts pharmaceutical particles from entering the central nervous system (CNS) from side to side of blood-brain barrier (BBB) [36]. In carcinoma cells, P-gp expression is linked to MDR1 causing failure in the treatment of cancer $[37,38]$. Numerous drugs and chemicals have been stated to rise Pgp appearance in Caco-2 cells, as in R-cetirizine [39], cadmium [40] and benzo(e)-pyrene [41]. The therapeutic outcome of $\mathrm{P}$-gp is the reduction in drug concentration through the target tissue [42] and also decrease in drug bioavailability [43] as P-gp deficiency in mice resulted in enhanced BA of drugs such as tacrolimus [44]. Therefore, P-gp is regarded as an obstacle against the absorption of the molecules in the intestine. Compounds that are capable of attenuating this pathway, became significant and dominant due to their ability to increase the drug bioavailability by reducing the expression of MDR1 or the activity thereof [45]. Various agents have been reported as inhibitors of the intestinal efflux pump. Tween 80 which is used in many of the pharmaceutical preparations, for example, has been reported in an in-vitro study as an inhibitor of P-gp where it is shown to be able of decreasing the transport of Rho- 123 from side to side of rat jejunal membrane through Caco-2 cells [46]. Also tween 20 and 80 have been shown to increase the transport rate of digoxin [47]. On the other hand, the effects and the influence of the excipients which are meant for this study have not been evaluated whether to possess the ability of making a change in the activity of P-gp, nor about the expression.

In this study, Carbopol 934 caused a significant rise in Rhodamine accumulation. This growth of the Rhodamine- 123 was $43 \%$. (Rhodamine accumulated inside the cells $=3938 \mathrm{pg} / \mathrm{mL}$; overall protein mass $=81$ $\mathrm{mg} / \mathrm{mL}$ ). Methylparaben, Sodium benzoate, CTAB, Tragacanth, Xanthan, HPMC K4M and HPMC K15M had a parallel blotting and Rho-123 assay results as the control group. On the other hand, Methylcellulose presented to have a significant rise in Rhodamin-123 accumulation. The increase was as high as $50.9 \%$. (Rhodamine accumulated inside the cells $=4155 \mathrm{pg} / \mathrm{mL}$; overall protein mass $=100 \mathrm{mg} / \mathrm{mL}$ ). Also vitamin E displayed 27.2\% growth in the amount of the Rho- 123 accumulated inside the cells (Rhodamine accumulated inside the cells $=3504 \mathrm{pg} / \mathrm{mL}$; overall protein mass $=97 \mathrm{mg} / \mathrm{mL}$ ).

The in vivo effects of Pegylated Vitamin E on P-gp substrates have been reported in preciding works. In consideration of the incorporation of Pegylated Vitamin E in the series of GRAS (Generally Recognised As Safe) substances by FDA, there has been an effort to include it in formulations to improve the bioavailability of drugs via inhibiting P-gp efflux pump [48]. In our study, data revealed that Vitamin E, Carbopol 934 and Methylcellulose, which are typically used as excipients in pharmaceutical industries, are operative in shrinking the P-gp production and for that reason playing an important role by means of obstructing the effluxion procedure. These findings may happened due to a novel mechanism that could be followed by an increased and improved amounts of the bioavailability index where some of the shrinkage in the Pgp efflux action may be explained through the depeletion of the expression of the protein after treatment accompanied by the excipients. Although finding the mechanism by which the named excipients could shrink the activity 
or expression of the P-gp, should be evaluated through more specific studies in molecular levels, etc. the common procedures may include the blockade of the binding site for the pharmaceutically active agents through intestinal efflux pump which can be either allosterically or competitively/noncompetitively or as a result of interfering with ATP hydrolysis, or even by means of changing the amounts of integrity of the cell membrane lipids. Thus, further studies is helpful to confirm the data obtained from this work and to define the underlying P-gp inhibitory mechanisms. Of course, this must be taken into consideration that as the drug and excipient decsend through the intestinal part, they would simillarly become diluted as a result of the presence of intestinal fluids and the activity of peristalsis. This would consequently decrease the efficacy of the inhibitor mainly in the face of rised levels of P-gp.

\section{CONCLUSION}

In the current research, data showed that the accumulation of Rhodamine- 123 through the Caco-2 cell line would be increased using Carbopol 934, Vitamin E and Methylcellulose excipients and P-gp expression through the membrane of the Caco-2 cells had been reduced as a result of its exposure to the excipients and preservatives, above. Data allows us to proposes hypotheses that may be tested by actual in vivo formulations of model dosage forms where using these polymers as efflux pump inhibitors would help to expand the bioavailability and intestinal penetrability and concentration. This work revealed that Carbopol 934, Vitamin E and Methylcellulose could be capable to improve drug absorption by means of preventing the P-gp activity; Then transportation of drugs which enter the intestinal cells and are candidates for Pgp efflux function, might be attenuated as a result of using Carbopo1934, Vitamin E and Methylcellulose in the mixture of drugexcipients. Finally, these records can help preparing novel pharmaceutical dosages which provide enhanced bioavailability, consequently. Regarding the fact that P-gp efflux pump works as a natural defense in human body, advantages and disadvantages of inhibiting that must be evaluated in the future works.

\section{MATERIALS AND METHODS}

\subsection{Materials}

Caco-2 cell line (Human carcinoma colorectal) was obtained from Iranian National Cell Bank, Pasteur institute, Iran. All cell culture one-use tools were attained from Orange, Belgium. RPMI 1640 - Powdered Cell Culture Medium was provided from PAA Co, Austria. Fetal Bovine Serum (FBS) was acquired from Gibco, Invitrogen, USA. Dimethyl sulfoxide (DMSO) was from Merck, Germany. Penicillin and streptomycin were acquired from Sigma, Germany. MTT reagent (3-(4,5-dimetylthiazol-2-yl)-2,5-diphenyltetrazolium bromide was obtained from Roche Diagnostics GmbH, Germany. Trypsin was provided from Gibco, Invitrogen, USA. All other chemicals were purchased from Merck Company, Germany.

\subsection{Caco-2 cell culture}

Under a laminar flow cabinet, we completed the procedures along with observing the typical sterile conditions. The cabinets were habitually sterilized during the night by exposing them to UV radial ion. Afterwards the cells were washed using 70\% alcohol. Cells were developed in RPMI 1640 medium with additional $10 \%$ fetal bovine serum (FBS), $100 \mu \mathrm{g} / \mathrm{ml}$ streptomycin and $100 \mathrm{U} / \mathrm{ml}$ penicillin. Then they were incubated into a humidified incubator containing $5 \% \mathrm{CO} 2$ at $37^{\circ} \mathrm{C}$. Afterwards cells were sub-cultured into 96-well plates and 6-well plates throughout different steps of the work $[18,19]$.

\subsection{Cell viability assay}

Cytotoxic concentrations of the excipients were calculated in Caco-2 cells by means of MTT reagent (3(4,5-dimetylthiazol-2-yl)-2,5-diphenyltetrazolium bromide. In this method, viable cells metabolize yellow tetrazolium salt MTT to purple formazan crystals by mitochondrial dehydrogenases. The cells were seeded in 96-well plates with a mass of 104 cells per well and incubated for $24 \mathrm{~h}$ at $37^{\circ} \mathrm{C}$ and $5 \% \mathrm{CO}$. Then the cells were treated with various concentrations $(10,20,50,100,150,200,300,400 \mu \mathrm{g} / \mathrm{ml})$ and $0.2 \%(\mathrm{v} / \mathrm{v})$ DMSO as a negative control. After 12, 24 and $48 \mathrm{~h}$ treatment $10 \mu \mathrm{l}$ of MTT labeling reagent was added to all wells. The plates were kept at $37^{\circ} \mathrm{C}$ and $5 \% \mathrm{CO} 2$ for 4 hours. Then, $100 \mu l$ of the solubilization solution was added to each well and subsequently incubated during the night at $37^{\circ} \mathrm{C}$ to dissolve formazan crystals. As a final point, absorbance was read by means of an ELISA plate reader (Bio Teck, Germany) at a wavelength of $570 \mathrm{~nm}$. The percentage of cytotoxicity and cell viability were estimated using following equations [20, 21]: 


$$
\begin{aligned}
& \% \text { Cytotoxicity }=1-\text { [mean absorbance of treated cells / mean absorbance of negative control] } \\
& \% \text { Viability }=100 \text { - \% Cytotoxicity. }
\end{aligned}
$$

\subsection{Rhodamine-123 uptake assessment}

In order to assess the uptake of Rho-123 (Rhodamine) Caco-2 cells were seeded into 24-well plates and left for 24 hours. A day after that, old medium was replaced and cells were washed down with 0.01M PBS (Phosphate Buffer Saline) where the $\mathrm{pH}$ was adjusted at 7.4. Then fresh culture media including defined concentrations of excipients and $0.3 \mathrm{mM}$ verapamil, as P-gp inhibitor, were added and left for another 24 hours. On the day 3 of experiment, the previous medium was removed and cells were washed down three times through PBS and Rho-123 solution (RPMI containing $10 \mathrm{mM}$ HEPES (pH=7.4) and $5 \mu \mathrm{M}$ Rho-123 were added and incubated in $37^{\circ} \mathrm{C}$ for 3 hours. After incubation phase, Rho-123 solution was detached and cells were washed three times with ice-cold PBS. Cells were lysed in 1\% Triton X-100 and centrifuged in $1000 \mathrm{rpm}$ for 5 minutes. Supernatant was utilized to calculate the fluorescence and total protein content. Amount of Rho123 was calculated using the plotted calibration curve (R2=1). Then cellular Rho-123 accumulation was normalized to total protein content determined by protein assay kit [49].

\subsection{Western blotting}

Cells were transferred to 6-well plate in mass of 106 cells per well and treated with excipients for 24 hours. Solutions were eliminated and cells were washed down by PBS and then incubated in $37^{\circ} \mathrm{C}$ for 5 minutes with Trypsin/EDTA $0.25 \%$. Supernatant was detached and cell sediment was washed for two times with PBS. Lysis buffer was poured and cell suspension was centrifuged in $15000 \mathrm{rpm}$ for 5 minutes. The proteins were alienated by electrophoresis through SDS-polyacrylamide gel on $12.5 \%$ running gel and $4 \%$ stacking gel at $80 \mathrm{~V}$ for 120 minutes. The gel was electro-blotted to Polyvinylidene difluoride (PVDF) membrane by means of semi-dry western blotting. 3\% non-fat dry milk was used to block the membrane for 1 hour at room temperature and membrane was washed down for 3 times with PBS-Tween $200.1 \%$. Afterwards, we incubated them during the night with primary monoclonal antibody (Anti- $\beta$-actin), diluted $1 / 1000$ in PBS having $0.1 \%$ tween 20 . $\beta$-actin was considered as the internal standard and was detected using rabbit polyclonal anti- $\beta$-actin (AB16039, Abcam) as the primary antibody and HRP-conjugated goat anti-rabbit IgG (AP7181, Razi Biotech) as the secondary antibody. P-gp expression was presented as the ratio of intensity of the P-gp band to the $\beta$-actin band in the same blot run (P-gp/ $\beta$-actin) [50] .

Subsequently, after washing by PBS-Tween 20 0.1\%, the membrane was incubated with horseradish peroxidase-conjugated Rabbit anti-mouse secondary antibody for about two hours. Membrane was washed and solution A and B of Enhanced chemiluminescence (ECL) kit was added, then membrane was exposed to X-ray film. Membrane was washed for two times and was incubated with MDR1 Antibody (C219) overnight. After washing, membrane was placed into horseradish peroxidase-conjugated Rabbit anti-mouse secondary antibody for two hours. Membrane was washed and then solution A and B of ECL kit was added, then membrane was exposed to X-ray film according to the instructions of the manufacturer [21, 22]. Finally, expression in treatment groups were compared with P-gp expression in untreated control cells.

\subsection{Statistical analysis}

The data was expressed as mean \pm SD. Statistical analysis was carried out using one-way analysis of variance (ANOVA) followed by Tukey's multiple comparison test. The differences between groups were determined using the unpaired t-test with SPSS 13.0 and was considered significant at $\mathrm{P}<0.05$ and $\mathrm{P}<0.01$.

Acknowledgements: This research was financially supported by Drug Applied Research Center, Tabriz University of Medical Sciences and the authors want to acknowledge the authorities thereof. Also we should state that this article is founded on a thesis submitted for PharmD degree (Number 3664) within Faculty of Pharmacy, Tabriz University of Medical Sciences, Tabriz, Iran.

Author contributions: Concept - R.M., P.ZM.; Design - H.V., P.ZM.,; Supervision - B.B., P.ZM.; Materials - R.M., B.Y., B.B.; Data Collection and/or Processing - R.M., B.Y., P.ZM.; Analysis and/or Interpretation - R.M., H.V., P.ZM.; Literature Search - R.M., P.ZM.; Writing - R.M., B.B., B.Y., H.V., P.ZM.; Critical Reviews - R.M., B.B., B.Y., H.V., P.ZM.

Conflict of interest statement: The authors declared no conflict of interest in the manuscript. 


\section{REFERENCES}

[1] Fuhrmann K, Fuhrmann G. Recent advances in oral delivery of macromolecular drugs and benefits of polymer conjugation. Curr Opin Colloid Interface Sci. 2017; 31: 67-74. [CrossRef]

[2] Ma Y, Fan X, Li L. pH-sensitive polymeric micelles formed by doxorubicin conjugated prodrugs for co-delivery of doxorubicin and paclitaxel. Carbohydr Polym. 2016; 137: 19-29. [CrossRef]

[3] Mahmood A, Bernkop-Schnürch A. SEDDS: A game changing approach for the oral administration of hydrophilic macromolecular drugs. Adv Drug Deliv Rev. 2018; pii: S0169-409X(18)30165-0. [CrossRef]

[4] Budha NR, Frymoyer A, Smelick GS, Jin JY, Yago MR, Dresser MJ, Holden SN, Benet LZ, Ware JA. Drug absorption interactions between oral targeted anticancer agents and PPIs: Is pH-dependent solubility the Achilles heel of targeted therapy? Clin Pharmacol Ther. 2012; 92(2): 203-213. [CrossRef]

[5] Darwich AS, Neuhoff S, Jamei M, Rostami-Hodjegan A. Interplay of metabolism and transport in determining oral drug absorption and gut wall metabolism: a simulation assessment using the "Advanced Dissolution, Absorption, Metabolism (ADAM)" model. Curr Drug Metab. 2010; 11(9): 716-729. [CrossRef]

[6] Jaferian S, Soleymaninejad M, Daraee H. Verapamil (VER) enhances the cytotoxic effects of docetaxel and vinblastine combined therapy against non-small cell lung cancer cell lines. Drug Res. 2018; 68(3): 146-152. [CrossRef]

[7] Sita G, Hrelia P, Tarozzi A, Morroni F. P-glycoprotein (ABCB1) and oxidative Stress: Focus on Alzheimer's disease. Oxid Med Cell Longev. 2017; 2017(7905486): 1-13. [CrossRef]

[8] Sugano K, Kansy M, Artursson P, Avdeef A, Bendels S, Di L, Ecker GF, Faller B, Fischer H, Gerebtzoff G, Lennernaes $\mathrm{H}$, Senner F. Coexistence of passive and carrier-mediated processes in drug transport. Nat Rev Drug Discov. 2010; 9(8): 597-614. [CrossRef]

[9] Zahir-Jouzdani F, Lupo N, Hermann M, Prufert F, Atyabi F, Bernkop Schnurch A. Glyceryl ester surfactants: Promising excipients to enhance the cell permeating properties of SEDDS. Eur J Pharm Biopharm. 2018; 129: $154-161$. [CrossRef]

[10] Chow EC, Talattof A, Tsakalozou E, Fan J, Zhao L, Zhang X. Using physiologically based pharmacokinetic (PBPK) modeling to evaluate the impact of pharmaceutical excipients on oral drug absorption: Sensitivity analyses. AAPS J. 2016; 18(6): 1500-1511. [CrossRef]

[11] Vaithianathan S, Haidar SH, Zhang X, Jiang W, Avon C, Dowling TC, Shao C, Kane M, Hoag SW, Flasar MH, Ting TY, Polli JE. Effect of common excipients on the oral drug absorption of biopharmaceutics classification system class 3 drugs cimetidine and acyclovir. J Pharm Sci. 2016; 105(2): 996-1005. [CrossRef]

[12] Zhang W, Li Y, Zou P, Wu M, Zhang Z, Zhang T. The effects of pharmaceutical excipients on gastrointestinal tract metabolic enzymes and transporters-an update. AAPS J. 2016; 18(4): 830-843. [CrossRef]

[13] Jain M, Dave D, Jain P, Manohar B, Yadav B, Shetty N. Efficacy of xanthan based chlorhexidine gel as an adjunct to scaling and root planing in treatment of the chronic periodontitis. J Indian Soc Periodontol. 2013; 17(4): 439-443. [CrossRef]

[14] Pahuja P, Arora S, Pawar P. Ocular drug delivery system: a reference to natural polymers. Expert Opin Drug Deliv. 2012; 9(7): 837-861. [CrossRef]

[15] Llamas-Moreno JF, Baiza-Duran LM, Saucedo-Rodriguez LR, Alaniz-De la OJ. Efficacy and safety of chondroitin sulfate/xanthan gum versus polyethylene glycol/propylene glycol/hydroxypropyl guar in patients with dry eye. Clin Ophthalmol. 2013; 7: 995-999. [CrossRef]

[16] Barta CA, Sachs-Barrable K, Feng F, Wasan KM. Effects of Monoglycerides on P-Glycoprotein: Modulation of the Activity and Expression in Caco-2 Cell Monolayers. Mol Pharm. 2008; 5(5): 863-875. [CrossRef]

[17] Groves E, Chaw CS. Incorporation of calcium salts into xanthan gum matrices: Hydration, erosion and drug release characteristics. Drug Dev Ind Pharm. 2015; 41(10): 1608-1616. [CrossRef]

[18] Ghayempour S, Montazer M, Mahmoudi Rad M. Tragacanth gum as a natural polymeric wall for producing antimicrobial nanocapsules loaded with plant extract. Int J Biol Macromol. 2015; 81: 514-520. [CrossRef]

[19] Florence AT, Jani PU. Novel oral drug formulations. Their potential in modulating adverse effects. Drug Saf. 1994; 10(3): 233-266. [CrossRef]

[20] Pahan K. Immunomodulation of experimental allergic encephalomyelitis by cinnamon metabolite sodium benzoate. Immunopharmacol Immunotoxicol. 2011; 33(4): 586-593. [CrossRef] 
[21] Afshar M, Moallem SA, Khayatzadeh J, Shahsavan M. Teratogenic effects of long term consumption of potassium benzoate on eye development in BALB/c fetal mice. Iran J Basic Med Sci. 2013; 16(4): 593-598. [CrossRef]

[22] Mamani PL, Ruiz-Caro R, Veiga MD. Matrix tablets: The effect of hydroxypropyl methylcellulose/anhydrous dibasic calcium phosphate ratio on the release rate of a water-soluble drug through the gastrointestinal tract I. In vitro tests. AAPS Pharm Sci Tech. 2012; 13(4): 1073-1083. [CrossRef]

[23] Li CL, Martini LG, Ford JL, Roberts M. The use of hypromellose in oral drug delivery. J Pharm Pharmacol. 2015; 57(5): 533-546. [CrossRef]

[24] Stabenfeldt SE, Garcia AJ, LaPlaca MC. Thermoreversible laminin-functionalized hydrogel for neural tissue engineering. J Biomed Mater Res A. 2016; 77(4): 718-725. [CrossRef]

[25] Stabenfeldt SE, LaPlaca MC. Variations in rigidity and ligand density influence neuronal response in methylcelluloselaminin hydrogels. Acta Biomater. 2011; 7(12): 4102-4108. [CrossRef]

[26] Goswami N, Gupta VR, Jogia HA. Development and validation of a novel stability-indicating RP-HPLC method for the simultaneous determination of halometasone, fusidic acid, methylparaben, and propylparaben in topical pharmaceutical formulation. Sci Pharm. 2013; 81(2): 505-518. [CrossRef]

[27] Roy C, Chakrabarty J, Modi PB. Validated stability-indicating reverse-phase ultra-performance liquid chromatography method for simultaneous determination of sodium methylparaben, sodium propylparaben and ketorolac tromethamine in topical dosage forms. Indian J Pharm Sci. 2013; 75(2): 197-204. [CrossRef]

[28] Kumar PA, Raju TV, Thirupathi D, Kumar R, Shree J. Development and validation of a stability-indicating lc-method for the simultaneous estimation of levodropropizine, chloropheniramine, methylparaben, propylparaben, and levodropropizine impurities. Sci Pharm. 2013; 81(1): 139-150. [CrossRef]

[29] Ito E, Yip KW, Katz D, Fonseca SB, Hedley DW, Chow S, Xu GW, Wood TE, Bastianutto C, Schimmer AD, Kelley SO, Liu FF. Potential use of cetrimonium bromide as an apoptosis-promoting anticancer agent for head and neck cancer. Mol Pharmacol. 2019; 76(5): 969-983. [CrossRef]

[30] Brigelius-Flohe R, Traber MG. Vitamin E: Function and metabolism. FASEB J. 1999; 13(10): 1145-1155. [CrossRef]

[31] Gradauer K, Dunnhaupt S, Vonach C, Szollosi H, Pali-Scholl I, Mangge H, Jensen-Jarolim E, Bernkop-Schnurch A, Prassl R. Thiomer-coated liposomes harbor permeation enhancing and efflux pump inhibitory properties. J Control Release. 2013; 165(3): 207-215. [CrossRef]

[32] Schinkel AH, Jonker JW. Mammalian drug efflux transporters of the ATP binding cassette (ABC) family: An overview. Adv Drug Deliv Rev. 2013; 55(1): 3-29. [CrossRef]

[33] Sharma M, Prasad R. The quorum-sensing molecule farnesol is a modulator of drug efflux mediated by ABC multidrug transporters and synergizes with drugs in Candida albicans. Antimicrob Agents Chemother. 2011; 55(10): 4834-4843. [CrossRef]

[34] Shaikh SA, Li J, Enkavi G, Wen PC, Huang Z, Tajkhorshid E. Visualizing functional motions of membrane transporters with molecular dynamics simulations. Biochemistry. 2013; 52(4): 569-587. [CrossRef]

[35] Kumar YS, Adukondalu D, Sathish D, Vishnu YV, Ramesh G, Latha AB, Reddy PC, Sarangapani M, Rao YM. PGlycoprotein and cytochrome P450 mediated herbal drug interactions. Drug Metabol Drug Interact. 2010; 25(1-4): 316. [CrossRef]

[36] Sane R, Agarwal S, Mittapalli RK, Elmquist WF. Saturable active efflux by p-glycoprotein and breast cancer resistance protein at the blood-brain barrier leads to nonlinear distribution of elacridar to the central nervous system. J Pharmacol Exp Ther. 2013; 345(1): 111-124. [CrossRef]

[37] Nanayakkara AK, Follit CA, Chen G, Williams NS, Vogel PD, Wise JG. Targeted inhibitors of P-glycoprotein increase chemotherapeutic-induced mortality of multidrug resistant tumor cells. Sci Rep. 2018; 8(1): 967. [CrossRef]

[38] To KKW, Wu X, Yin C, Chai S, Yao S, Kadioglu O, Efferth T, Ye Y, Lin G. Reversal of multidrug resistance by Marsdenia tenacissima and its main active ingredients polyoxypregnanes. J Ethnopharmacol. 2017; 203: 110-119. [CrossRef]

[39] Shen, S., Y. He, and S. Zeng. Stereoselective regulation of MDR1 expression in Caco-2 cells by cetirizine enantiomers. Chirality. 2017; 19(6): 485-490. [CrossRef]

[40] Huynh-Delerme C, Huet H, Noël L, Frigieri A, Kolf-Clauw M. Increased functional expression of P-glycoprotein in Caco-2 TC7 cells exposed long-term to cadmium. Toxicol In Vitro. 2015; 19(4): 439-447. [CrossRef] 
[41] Sugihara N, Toyama K, Michihara A, Akasaki K, Tsuji H, Furuno K. Effect of benzo[a]pyrene on P-glycoproteinmediated transport in Caco-2 cell monolayer. Toxicology. 2006; 223(1-2): 156-165. [CrossRef]

[42] Fromm, M.F. P-Glycoprotein: A Defense Mechanism Limiting Oral Bioavailability and CNS Accumulation of Drugs. Int J Clin Pharmacol Ther. 2010; 38: 69-74. [CrossRef]

[43] Takano, M., R. Yumoto, and T. Murakami. Expression and function of efflux drug transporters in the intestine. Pharmacol Ther. 2016; 109(1): 137-161. [CrossRef]

[44] Krogstad V, Vethe NT, Robertsen I, Hasvold G, Ose AD, Hermann M, Andersen AM, Chan J, Skauby M, Svensson MHS, Asberg A, Christensen H. Determination of tacrolimus concentration and protein expression of P-glycoprotein in single human renal core biopsies. Ther Drug Monit. 2018; 40(3): 292-300. [CrossRef]

[45] Wang J, Gan C, Sparidans RW, Wagenaar E, van Hoppe S, Beijnen JH, Schinkel AH. P-glycoprotein (MDR1/ABCB1) and breast cancer resistance protein (BCRP/ABCG2) affect brain accumulation and intestinal disposition of encorafenib in mice. Pharmacol Res. 2018; 129: 414-423. [CrossRef]

[46] Rege, B.D., J.P. Kao, and J.E. Polli. Effects of nonionic surfactants on membrane transporters in Caco-2 cell monolayers. Eur J Pharm Sci. 2012; 16(4-5): 237-246. [CrossRef]

[47] Zhang H, Yao M, Morrison RA, Chong S. Commonly used surfactant, Tween 80, improves absorption of Pglycoprotein substrate, digoxin, in rats. Arch Pharmacal Res. 2013; 26(9): 768-772. [CrossRef]

[48] Gurjar R, Chan CYS, Curley P, Sharp J, Chiong J, Rannard S, Siccardi M, Owen A. Inhibitory effects of commonly used excipients on P-glycoprotein in vitro. Mol Pharm. 2018; 15(11): 4835-4842. [CrossRef]

[49] Mohammadzadeh R, Baradaran B, Valizadeh H, Yousefi B, Zakeri-Milani P. Reduced ABCB1 expression and activity in the presence of acrylic copolymers. Adv Pharm Bull. 2014; 4(3): 219-224. [CrossRef]

[50] Mesgari Abbasi M, Valizadeh H, Hamishekar H, Mohammadnejad L, Zakeri-Milani P. The effects of cetirizine on Pglycoprotein expression and function in vitro and in situ. Adv Pharm Bull. 2016; 6(1): 111-118. [CrossRef]

This is an open access article which is publicly available on our journal's website under Institutional Repository at http://dspace.marmara.edu.tr. 